\title{
ANALISIS BIAYA PRELIMINARIES PROYEK BANGUNAN GEDUNG BERTINGKAT (STUDI PADA PERUSAHAAN KONTRAKTOR X)
}

\author{
Rafael Devin $^{1}$, Onnyxiforus Gondokusumo ${ }^{2}$ \\ ${ }^{1}$ Mahasiswa Magister Teknik Sipil, Universitas Tarumanagara \\ rafaeldevin@yahoo.com \\ ${ }^{2}$ Dosen Magister Teknik Sipil, Universitas Tarumanagara \\ onnyxiforusg@pps.untar.ac.id
}

\begin{abstract}
ABSTRAK
Biaya preliminaries adalah sebuah biaya pendukung dalam sebuah proyek konstruksi yang tidak menghasilkan secara fisik sebagai suatu bangunan. Biaya preliminaries merupakan suatu komponen penting dalam anggaran proyek karena pada umumnya merupakan kunci yang menentukan keuntungan maupun kerugian sebuah proyek konstruksi. Berdasarkan pengalaman yang sudah terjadi selama ini, hampir semua biaya realisasi preliminaries proyek menyimpang dari anggaran yang sudah disepakati di awal. Tentunya akan menjadi suatu kerugian besar bagi kontraktor apabila semua proyek berjalan mengalami hal yang sama seperti ini. Penentuan rasio biaya preliminaries diperlukan dalam penyusunan Rencana Anggaran Pelaksanaan (RAP). Pada umumnya, penentuan biaya preliminaries dilakukan tanpa memperhatikan tipe proyek yang akan dilaksanakan, hanya dilakukan berdasarkan kuantitas kebutuhan yang ada. Pada penelitian ini, tipe proyek yang ditinjau adalah tipe proyek Hotel, tipe proyek Kantor, dan tipe proyek Mall. Persentase biaya Realisasi (REAL) pada ketiga tipe proyek tersebut selalu lebih besar dari anggaran awal yang telah disepakati yaitu nilai Real Cost $(R C)$ dan nilai RAP. Persentase biaya preliminaries antara tipe proyek Hotel dan tipe proyek Kantor berada pada persentase 11,24\%-13,61\%, sedangkan tipe proyek Mall berada pada persentase 8,31\%-8,84\%. Hubungan antara RC dan RAP adalah memiliki nilai yang relatif tidak jauh berbeda dengan deviasi sekitar 0,5\%, sedangkan Realisasi cenderung selalu lebih besar daripada RAP dengan deviasi sekitar 1,8\%. Biaya preliminaries jika diurutkan dari persentase yang paling dominan adalah biaya karyawan, biaya peralatan, biaya persiapan, biaya umum, dan biaya keuangan. Dari hasil analisis regresi dapat disimpulkan bahwa variabel Total Nilai Kontrak Proyek sangat berpengaruh terhadap Realisasi Preliminaries dengan koefisien determinasi lebih dari $80 \%$.
\end{abstract}

Kata kunci: preliminaries, real cost (RC), rencana anggaran pelaksanaan (RAP), biaya realisasi (REAL)

\section{PENDAHULUAN}

Estimasi biaya preliminaries pada sebuah kontrak pekerjaan konstruksi adalah sebuah bagian penting dalam proses penyusunan anggaran awal sebuah proyek (Bell dan Kaminsky, 1987). Biaya preliminaries pada umumnya terbagi menjadi dua, yaitu biaya langsung dan biaya tidak langsung. Biaya tidak langsung terdiri dari 10\% sampai $40 \%$ atau lebih dari keseluruhan total biaya proyek konstruksi, dan sebagian hanya tergantung pada jenis dan sifat proyek (Becker et al., 2014). Menurut Hardie (1986), estimasi biaya terbagi menjadi dua, yaitu approximate estimates dan detailed estimates. Biaya preliminaries ini termasuk dalam detailed estimates karena merupakan suatu komponen penting dalam anggaran proyek karena pada umumnya merupakan kunci yang menentukan keuntungan maupun kerugian sebuah proyek konstruksi. Anggaran biaya preliminaries ada dua jenis, yaitu Real Cost (RC) dan Rencana Anggaran Pelaksanaan (RAP). RC merupakan biaya yang dibuat oleh estimator sebagai biaya awal yang ditargetkan kepada tim proyek dalam penyusunan RAP. Sedangkan RAP merupakan biaya yang dibuat oleh tim proyek sesuai dengan kondisi dan rencana di lapangan. Bagian ini melibatkan beberapa pihak terutama estimator dan tim proyek serta biaya yang termasuk biaya konstruksi dasar yang masih menjadi bagian dari anggaran proyek tersebut (O'Brien, 1994). Penelitian ini bertujuan untuk menghasilkan rasio biaya preliminaries agar digunakan sebagai acuan dasar untuk menentukan RC dan RAP; mencari penyebab penyimpangan biaya realisasi preliminaries terhadap RAP proyek; mencari item preliminaries yang berpengaruh pada keseluruhan biaya 
preliminaries; mengetahui hubungan yang terjadi antara biaya preliminaries dengan faktorfaktor lainnya yang berpengaruh.

\section{METODE PENELITIAN}

Tujuan utama dari estimasi biaya adalah menjelaskan biaya-biaya dari penggunaan sumber daya yang digunakan untuk mencapai kriteria barang atau jasa yang direncanakan (Diamant and Roy, 1990). Rencana penelitian ini pertama kali dimulai dengan melakukan upaya dalam mencari dan mengumpulkan data biaya preliminaries. Penulis mencari data biaya preliminaries proyek selesai antara tahun 2009-2016 di perusahaan kontraktor X. Penulis menggunakan data proyek selesai karena dapat dikatakan bahwa alur dan sirkulasi transaksi keuangan yang terjadi sudah selesai sehingga biaya yang tercantum dalam data sudah bersifat final dan tidak berubah lagi.

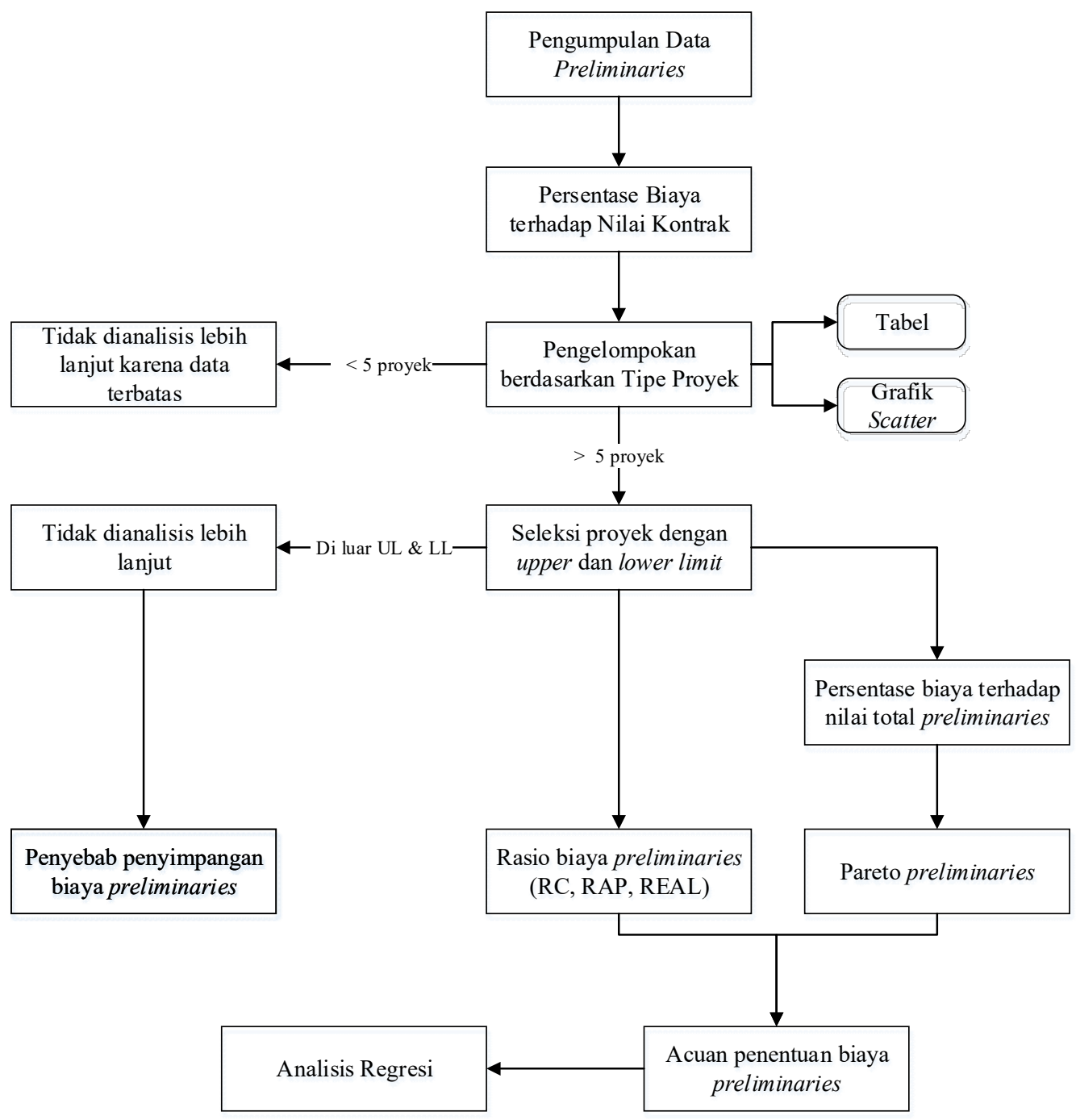

Gambar 1. Alur Penelitian 


\section{ANALISIS DATA}

\section{Grafik Total Biaya Preliminaries}

Analisis data diawali dengan mengumpulkan daftar proyek sehingga diperoleh tabel seperti pada Tabel 1 di bawah ini.

Tabel 1. Daftar Proyek

\begin{tabular}{|c|c|c|c|c|c|c|}
\hline No & Proyek & Tipe & Nilai Kontrak (Rp.) & RC & RAP & Real \\
\hline 1 & $\mathrm{H} 1$ & Hotel & 113.116 .539 .000 & $7,18 \%$ & $7,31 \%$ & $9,54 \%$ \\
\hline 7 & $\mathrm{H} 2$ & Hotel & 42.505 .822 .440 & $11,79 \%$ & $11,79 \%$ & $12,76 \%$ \\
\hline 12 & $\mathrm{H} 3$ & Hotel & 139.298 .500 .000 & $12,70 \%$ & $13,40 \%$ & $17,18 \%$ \\
\hline 14 & $\mathrm{H} 4$ & Hotel & 87.251 .882 .120 & $11,37 \%$ & $11,07 \%$ & $10,80 \%$ \\
\hline 27 & H5 & Hotel & 160.000 .000 .000 & $7,63 \%$ & $8,94 \%$ & $12,98 \%$ \\
\hline 53 & H6 & Hotel & 53.146 .680 .000 & $13,26 \%$ & $13,61 \%$ & $13,60 \%$ \\
\hline 54 & H7 & Hotel & 30.688 .175 .505 & $18,87 \%$ & $17,90 \%$ & $15,94 \%$ \\
\hline 55 & H8 & Hotel & 31.925 .991 .142 & $14,72 \%$ & $13,46 \%$ & $13,03 \%$ \\
\hline 5 & K1 & Kantor & 129.688 .715 .309 & $8,37 \%$ & $9,04 \%$ & $10,17 \%$ \\
\hline 16 & $\mathrm{~K} 2$ & Kantor & 124.914 .011 .488 & $11,61 \%$ & $11,61 \%$ & $12,16 \%$ \\
\hline 17 & K3 & Kantor & 25.430 .676 .200 & $18,13 \%$ & $18,44 \%$ & $18,44 \%$ \\
\hline 18 & K4 & Kantor & 46.860 .000 .000 & $11,04 \%$ & $11,04 \%$ & $14,15 \%$ \\
\hline 19 & K5 & Kantor & 20.004 .000 .000 & $10,03 \%$ & $10,03 \%$ & $17,30 \%$ \\
\hline 22 & K6 & Kantor & 293.500 .000 .000 & $8,53 \%$ & $8,98 \%$ & $7,83 \%$ \\
\hline 23 & K7 & Kantor & 37.950 .000 .000 & $10,56 \%$ & $10,67 \%$ & $12,57 \%$ \\
\hline 24 & K8 & Kantor & 39.628 .000 .000 & $10,62 \%$ & $10,62 \%$ & $8,94 \%$ \\
\hline 26 & K9 & Kantor & 143.000 .000 .000 & $7,63 \%$ & $7,71 \%$ & $8,37 \%$ \\
\hline 28 & K10 & Kantor & 59.000 .000 .000 & $15,03 \%$ & $16,07 \%$ & $19,40 \%$ \\
\hline 35 & K11 & Kantor & 149.068 .944 .672 & $10,28 \%$ & $10,26 \%$ & $12,57 \%$ \\
\hline 40 & K12 & Kantor & 102.525 .000 .000 & $6,61 \%$ & $8,77 \%$ & $10,24 \%$ \\
\hline 41 & K13 & Kantor & 219.487 .435 .846 & $12,83 \%$ & $13,34 \%$ & $13,73 \%$ \\
\hline 46 & K14 & Kantor & 50.927 .320 .322 & $21,10 \%$ & $20,40 \%$ & $23,23 \%$ \\
\hline 3 & M1 & Mall & 167.492. & $6,88 \%$ & $7,04 \%$ & $7,92 \%$ \\
\hline 20 & M2 & Mall & 33.859 .284 .086 & $7,77 \%$ & $7,99 \%$ & $9,61 \%$ \\
\hline 3 & M3 & Mall & 167.492 .2 & $6,88 \%$ & $7,04 \%$ & $7,92 \%$ \\
\hline 20 & M4 & Mall & 33.859 .284 .086 & $7,77 \%$ & $7,99 \%$ & $9,61 \%$ \\
\hline 29 & M5 & Mall & 1.263 .679 .200 .852 & $11,11 \%$ & $10,13 \%$ & $9,34 \%$ \\
\hline 42 & M6 & Mall & .500 .000 & $11,03 \%$ & $11,76 \%$ & $10,82 \%$ \\
\hline 43 & M7 & Mall & 61.728 .554 .132 & $9,89 \%$ & $11,38 \%$ & $13,04 \%$ \\
\hline 44 & M8 & Mall & 50.210 .050 .000 & $7,15 \%$ & $7,55 \%$ & $7,65 \%$ \\
\hline 47 & M9 & Mall & 39.160 .330 .000 & $8,11 \%$ & $8,25 \%$ & $7,51 \%$ \\
\hline 48 & M10 & Mall & 40.455 .690 .000 & $7,72 \%$ & $8,38 \%$ & $9,81 \%$ \\
\hline 49 & M11 & Mall & 39.603 .274 .102 & $8,00 \%$ & $6,03 \%$ & $7,86 \%$ \\
\hline 50 & M12 & Mall & 48.663 .738 .200 & $13,60 \%$ & $13,21 \%$ & $12,74 \%$ \\
\hline 51 & M13 & Mall & 43.448 .500 .000 & $8,14 \%$ & $8,50 \%$ & $8,48 \%$ \\
\hline 52 & M14 & Mall & 40.234 .700 .000 & $8,39 \%$ & $7,82 \%$ & $7,21 \%$ \\
\hline
\end{tabular}

\section{Pengelompokan Proyek}

\section{Tipe Proyek Hotel}

Sebaran dari Tabel 1 akan dimuat dalam grafik pada Gambar 2 sehingga dapat diketahui penyebaran data untuk tipe proyek Hotel. Gambar 2 juga akan mencantumkan upper limit dan lower limit untuk melakukan seleksi terhadap data yang berada di luar batas tersebut. Dalam penelitian ini, 3 data berupa RC, RAP, dan Real yang semuanya berada di luar batas tersebut tidak akan dianalisis lebih lanjut. Hal ini berlaku sama untuk tipe proyek Kantor dan Mall. 
Vol. 1, No. 1, April 2017: hlm 261-271

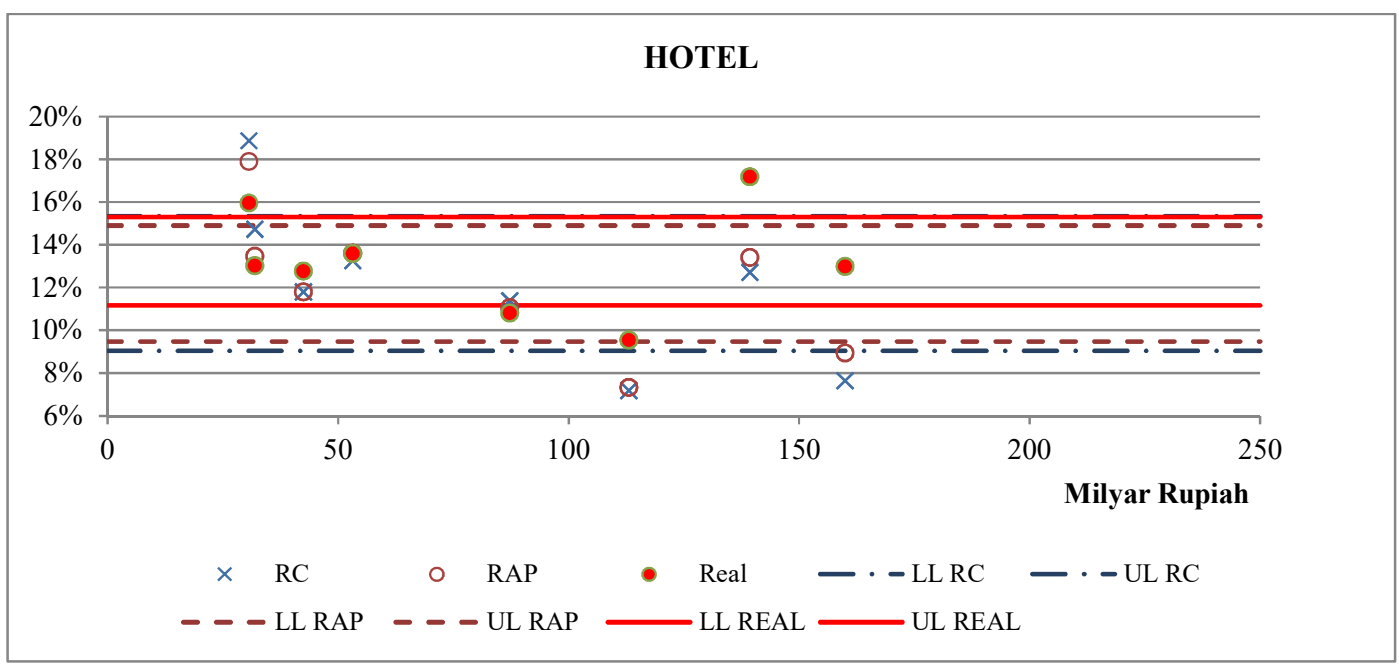

Gambar 2. Persentase RC-RAP-REAL Preliminaries Tipe Proyek Hotel

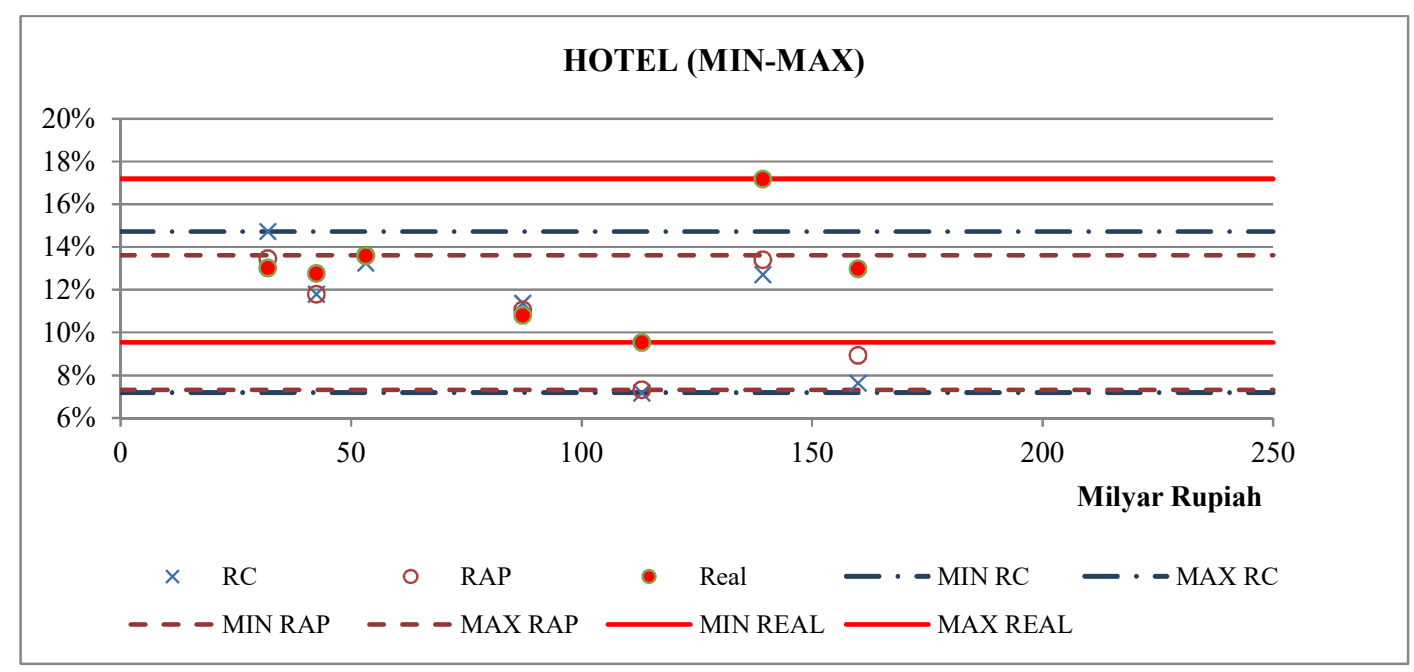

Gambar 3. Persentase RC-RAP-REAL Preliminaries (Seleksi) Tipe Proyek Hotel

Tabel 2 menampilkan nilai rata-rata, nilai maksimum, dan nilai minimum untuk biaya preliminaries tipe proyek Hotel.

Tabel 2. Daftar Proyek Tipe Hotel (Rata-rata, Maksimum, dan Minimum)

\begin{tabular}{ccccc}
\hline Tipe Proyek & Nilai & RC & RAP & REAL \\
\hline \multirow{2}{*}{ HOTEL } & Rata-rata & $11,24 \%$ & $11,37 \%$ & $12,84 \%$ \\
\cline { 2 - 5 } & Maks. & $14,72 \%$ & $13,61 \%$ & $17,18 \%$ \\
\cline { 2 - 5 } & Min. & $7,18 \%$ & $7,31 \%$ & $9,54 \%$ \\
\hline
\end{tabular}

\section{Tipe Proyek Kantor}

Gambar 4 juga akan mencantumkan upper limit dan lower limit untuk melakukan seleksi terhadap data yang berada di luar batas tersebut, sedangkan Gambar 5 menampilkan sebaran data yang sudah terseleksi. 


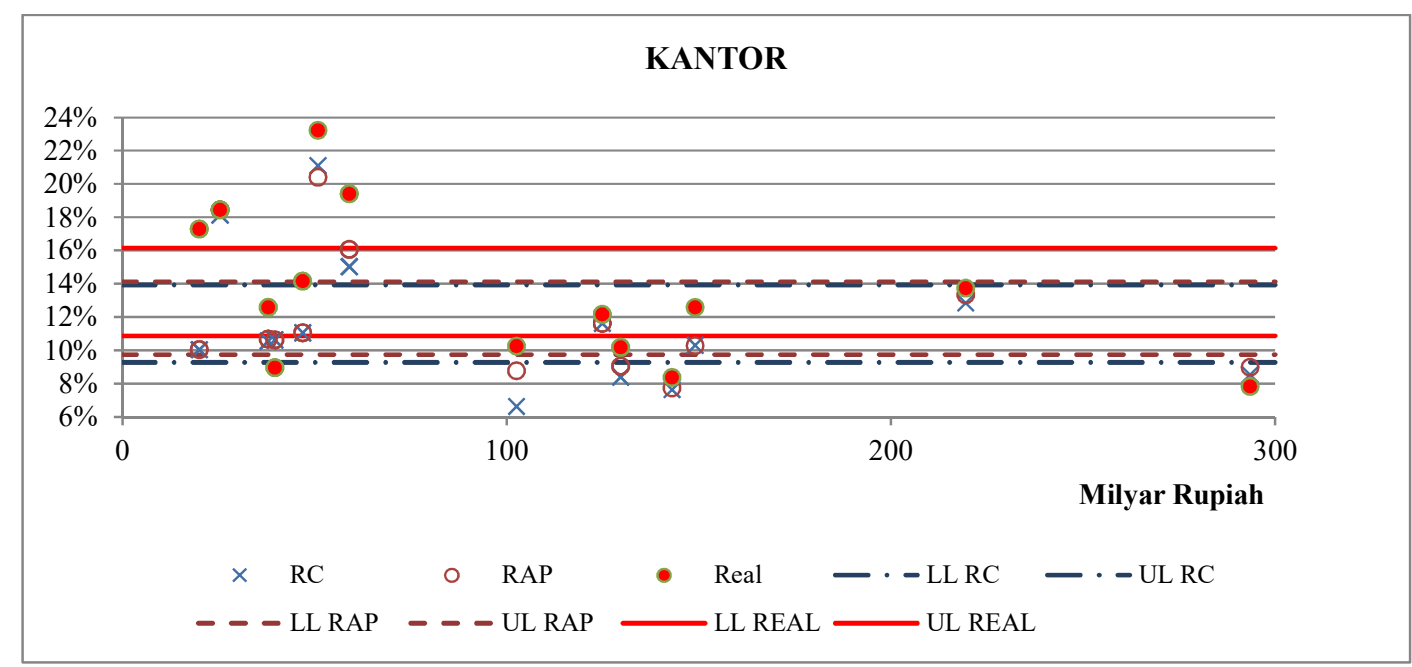

Gambar 4. Persentase RC-RAP-REAL Preliminaries Tipe Proyek Kantor

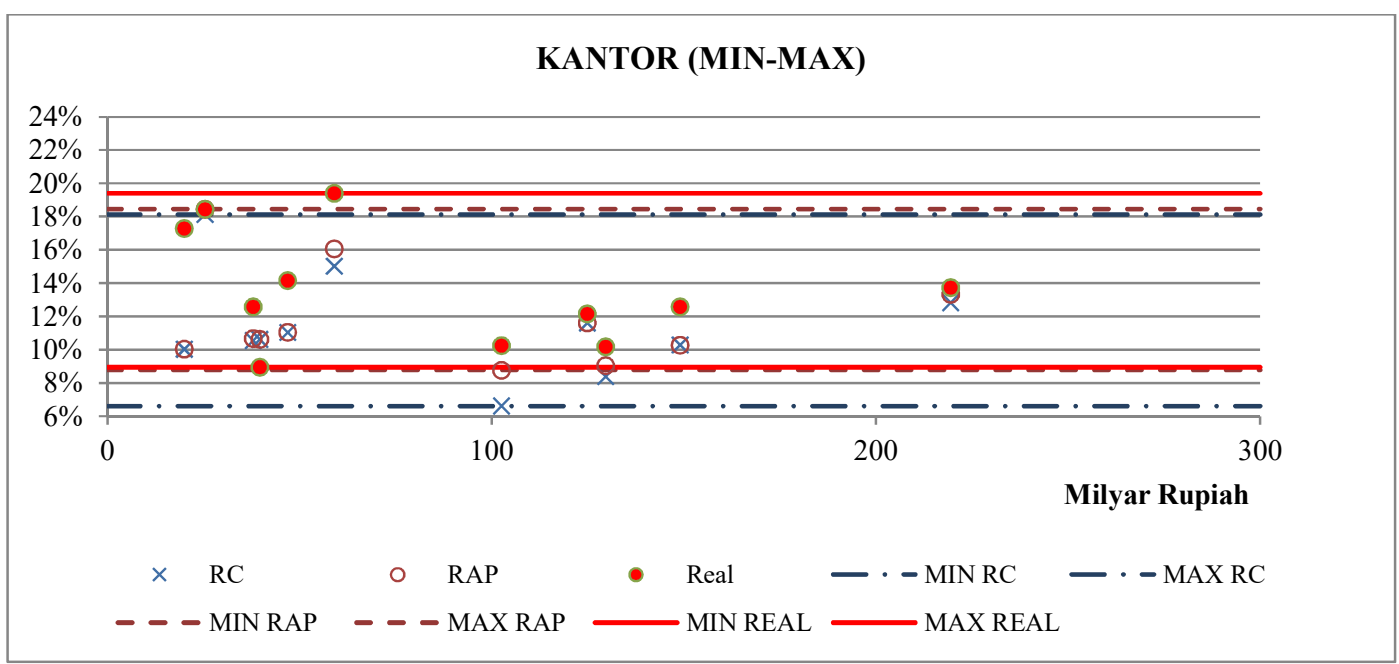

Gambar 5. Persentase RC-RAP-REAL Preliminaries (Seleksi) Tipe Proyek Kantor

Tabel 3 menampilkan nilai rata-rata, nilai maksimum, dan nilai minimum untuk biaya preliminaries tipe proyek Kantor.

Tabel 3. Daftar Proyek Tipe Kantor (Rata-rata, Maksimum, dan Minimum)

\begin{tabular}{ccccc}
\hline Tipe Proyek & Nilai & RC & RAP & REAL \\
\hline \multirow{3}{*}{ KANTOR } & Rata-rata & $11,37 \%$ & $11,81 \%$ & $13,61 \%$ \\
\cline { 2 - 5 } & Maks. & $18,13 \%$ & $18,44 \%$ & $19,40 \%$ \\
\cline { 2 - 5 } & Min. & $6,61 \%$ & $8,77 \%$ & $8,94 \%$ \\
\hline
\end{tabular}

\section{Tipe Proyek Mall}

Gambar 6 juga akan mencantumkan upper limit dan lower limit untuk melakukan seleksi terhadap data yang berada di luar batas tersebut, sedangkan Gambar 7 menampilkan sebaran data yang sudah terseleksi. 
Vol. 1, No. 1, April 2017: hlm 261-271

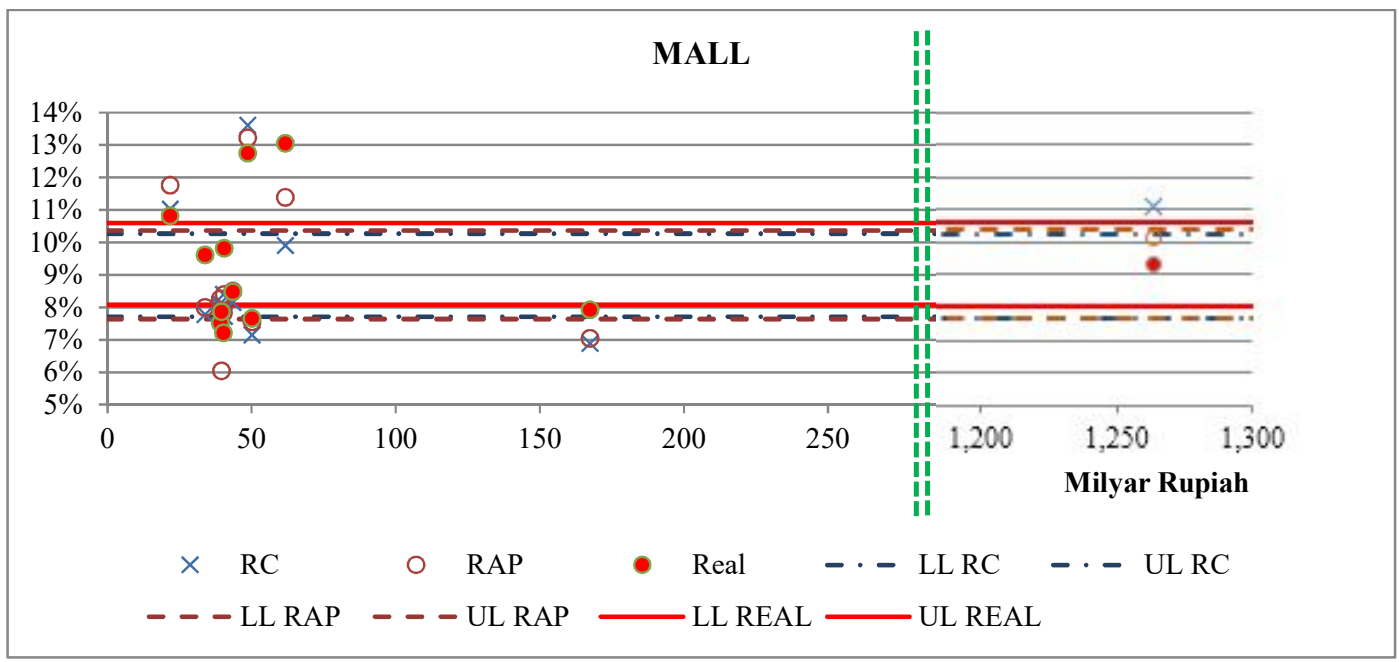

Gambar 6. Persentase RC-RAP-REAL Preliminaries Tipe Proyek Mall

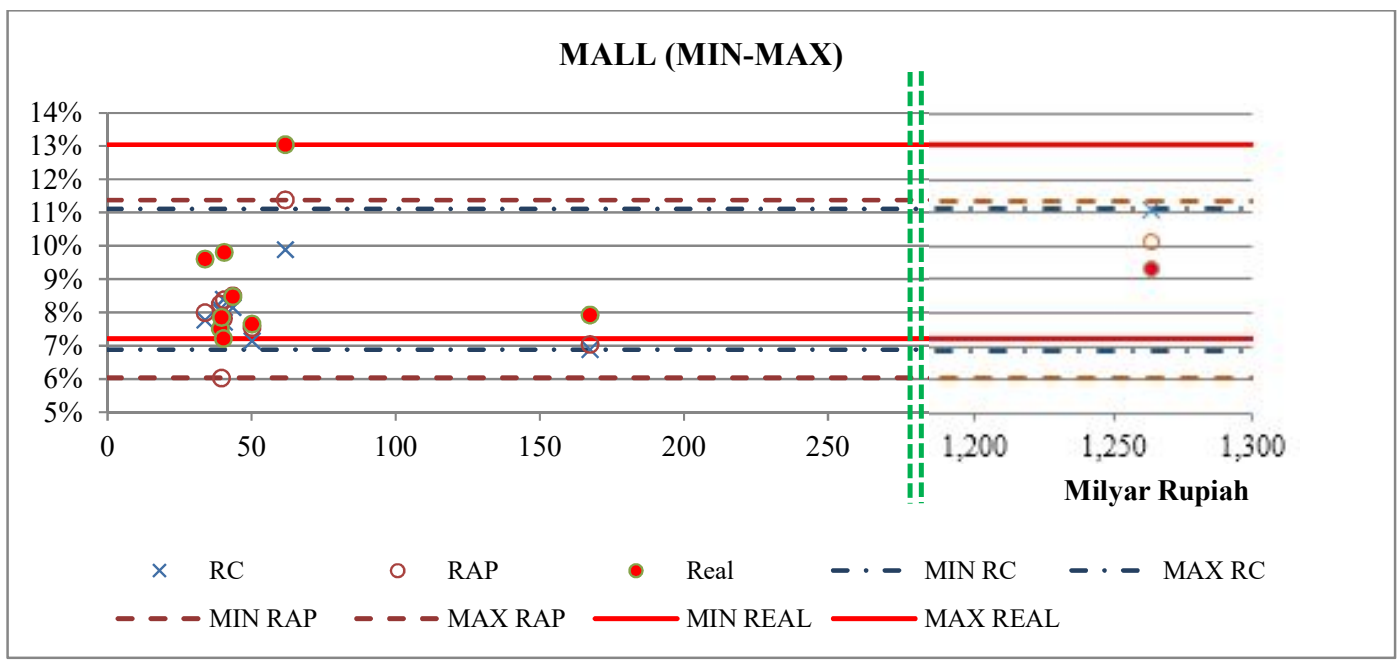

Gambar 7. Persentase RC-RAP-REAL Preliminaries (Seleksi) Tipe Proyek Mall

Tabel 4 menampilkan nilai rata-rata, nilai maksimum, dan nilai minimum untuk biaya preliminaries tipe proyek Mall.

Tabel 4. Daftar Proyek Tipe Mall (Rata-rata, Maksimum, dan Minimum)

\begin{tabular}{ccccc}
\hline Tipe Proyek & Nilai & RC & RAP & REAL \\
\hline \multirow{3}{*}{ MALL } & Rata-rata & $8,32 \%$ & $8,31 \%$ & $8,84 \%$ \\
\cline { 2 - 5 } & Maks. & $11,11 \%$ & $11,38 \%$ & $13,04 \%$ \\
\cline { 2 - 5 } & Min. & $6,88 \%$ & $6,03 \%$ & $7,21 \%$ \\
\hline
\end{tabular}

\section{Persentase Item Preliminaries}

Persentase untuk tiap 5 item preliminaries utama memiliki urutan dari tinggi ke rendah yang sama untuk setiap tipe proyek Hotel, Kantor, dan Mall. Urutan dari tinggi ke rendah yang dimaksud adalah biaya karyawan, biaya peralatan, biaya persiapan, biaya umum, dan biaya keuangan. Persentase biaya karyawan sebesar 35\%-45\%, biaya peralatan sebesar 25\%-34\%, 
biaya persiapan sebesar 14\%-19\%, biaya umum sebesar 11\%-15\%, dan biaya keuangan sebesar 1\%-3\%. Persentase-persentase tersebut dapat dilihat pada Gambar 8, 9, dan 10.

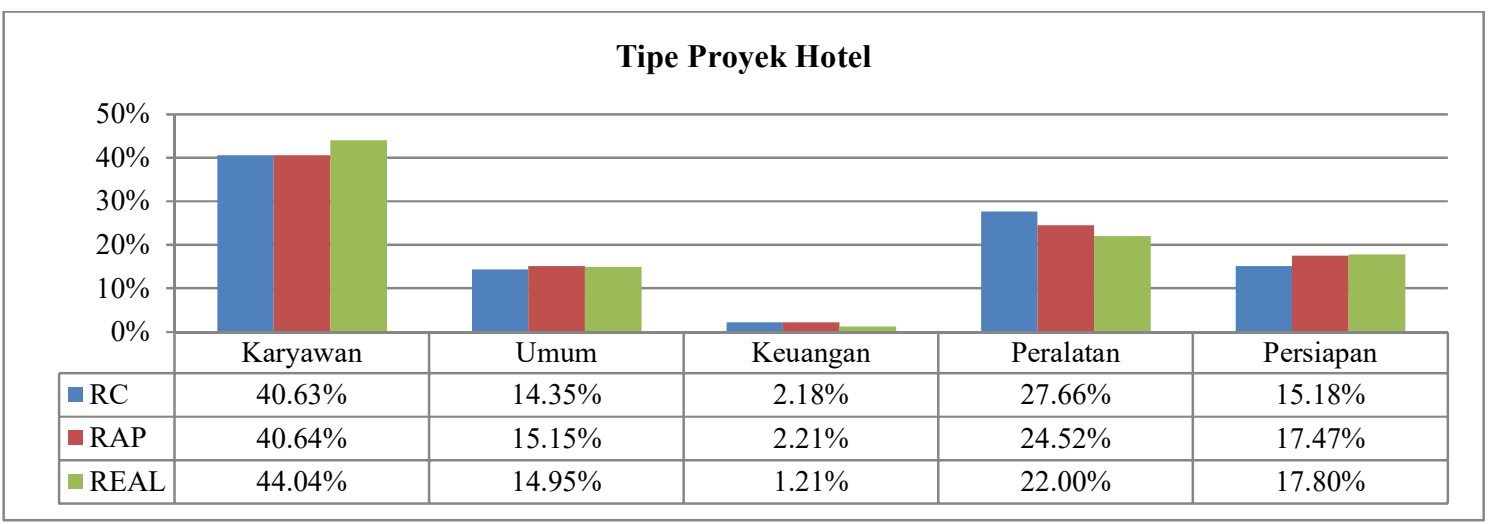

Gambar 8. Persentase Rata-Rata Tipe Proyek Hotel

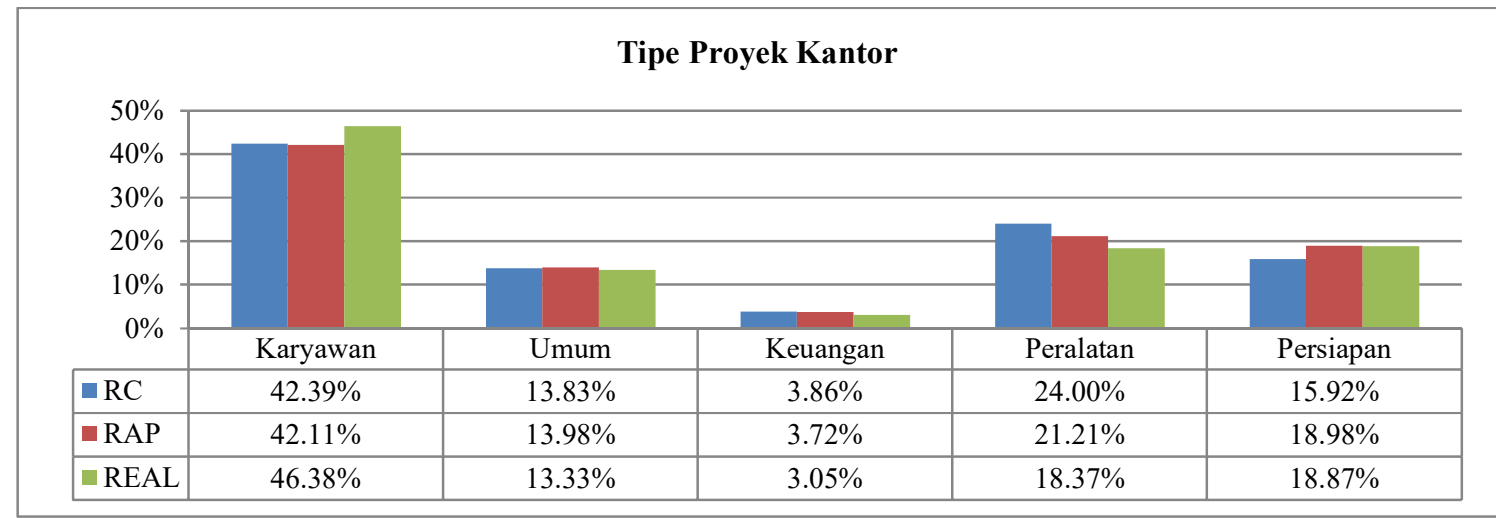

Gambar 9. Persentase Rata-Rata Tipe Proyek Kantor

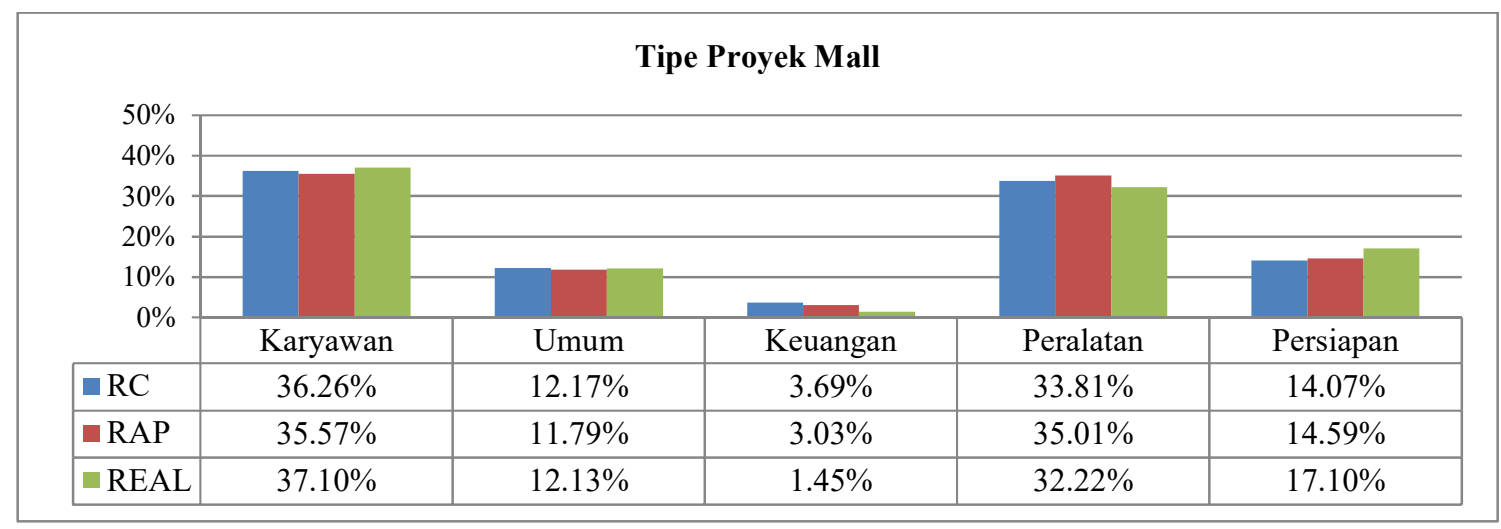

Gambar 10. Persentase Rata-Rata Tipe Proyek Mall

\section{Analisis Pareto Preliminaries}

Dengan melakukan analisis pareto maka kita dapat mengetahui seluruh item preliminaries yang mempengaruhi biaya preliminaries secara keseluruhan terutama item preliminaries yang 
termasuk dalam $80 \%$ biaya total preliminaries. Maka perlu dilakukan kontrol biaya terhadap item preliminaries yang selalu berada dalam $80 \%$ biaya preliminaries terbesar. Biaya preliminaries yang akan dilakukan analisis pareto dibatasi pada biaya Realisasi preliminaries saja. Pada tabel 5 berikut, akan ditampilan item-item preliminaries yang masuk dalam pareto $80 \%$. Semakin besar persentase maka semakin besar pengaruh item tersebut terhadap biaya preliminaries.

Tabel 5. Besaran Rata-rata Item Preliminaries Berdasarkan Pareto

\begin{tabular}{clrrr}
\hline \multirow{2}{*}{ No } & & HOTEL & KANTOR & MALL \\
\cline { 3 - 5 } & & Rata-rata & Rata-rata & Rata-rata \\
\hline 1 & Gaji staf pusat & $22,06 \%$ & $25,89 \%$ & $17,68 \%$ \\
\hline 2 & Tower crane & $8,45 \%$ & $9,27 \%$ & $12,97 \%$ \\
\hline 3 & Bahan bakar minyak (BBM) & $7,58 \%$ & $4,96 \%$ & $7,29 \%$ \\
\hline 4 & Keamanan proyek & $6,46 \%$ & $5,16 \%$ & $5,01 \%$ \\
\hline 5 & Kebersihan proyek & $6,14 \%$ & $4,82 \%$ & $3,78 \%$ \\
\hline 6 & Mobilisasi pekerja & $4,86 \%$ & $3,12 \%$ & $7,83 \%$ \\
\hline 7 & Scaffolding & $4,97 \%$ & $5,81 \%$ & $3,45 \%$ \\
\hline 8 & Gaji staf proyek & $5,13 \%$ & $5,11 \%$ & $2,99 \%$ \\
\hline 9 & Listrik kerja & $4,15 \%$ & $5,29 \%$ & $2,26 \%$ \\
\hline 10 & Mobilisasi staf & $2,84 \%$ & $4,06 \%$ & $3,43 \%$ \\
\hline 11 & Tunjangan daerah luar kota & $5,20 \%$ & $2,46 \%$ & $2,66 \%$ \\
\hline 12 & Tunjangan kendaraan & $2,81 \%$ & $3,63 \%$ & $2,25 \%$ \\
\hline 13 & Direksi keet & $0,00 \%$ & $2,54 \%$ & $2,53 \%$ \\
\hline 14 & Pagar proyek & $0,00 \%$ & $1,65 \%$ & $3,05 \%$ \\
\hline 15 & Lemburan staf & $2,35 \%$ & $2,46 \%$ & $2,64 \%$ \\
\hline 16 & Bedeng pekerja & $2,87 \%$ & $2,21 \%$ & $2,28 \%$ \\
\hline 17 & Safety & $2,58 \%$ & $2,56 \%$ & $1,60 \%$ \\
\hline 18 & Genset & $2,35 \%$ & $1,29 \%$ & $2,28 \%$ \\
\hline 19 & Uang makan staf & $2,46 \%$ & $1,75 \%$ & $1,75 \%$ \\
\hline 20 & Pengobatan staf & $1,97 \%$ & $1,88 \%$ & $1,54 \%$ \\
\hline
\end{tabular}

\section{Analisis Regresi}

Analisis regresi dilakukan untuk mencari hubungan di antara variabel-variabel yang sering dijadikan acuan dalam penentuan biaya preliminaries. Variabel tersebut antara lain nilai kontrak proyek, biaya realisasi preliminaries, durasi realisasi proyek, dan luas struktur. Dalam penelitian ini, biaya realisasi preliminaries akan menjadi variabel y sedangkan nilai kontrak proyek, durasi realisasi proyek, dan luas struktur akan menjadi variabel $\mathrm{x}$. Penelitian ini menggunakan tiga jenis variabel $\mathrm{x}$ sehingga persamaan regresi akan menjadi $\mathrm{y}=\mathrm{a}+\mathrm{bx}_{1}+\mathrm{bx}_{2}+\mathrm{bx}_{3}$. Peneliti akan menggunakan fasilitas dalam program SPSS untuk membantu dalam proses analisis regresi ini. Metode regresi yang digunakan adalah regresi linier berganda dan menggunakan metode stepwise.

Tabel 6. Hasil Analisis Regresi

\begin{tabular}{cccc}
\hline $\begin{array}{c}\text { Variabel independent } \\
\text { (variabel yang } \\
\text { mempengaruhi) }\end{array}$ & Tipe Proyek & $\begin{array}{c}\text { Koefisien } \\
\text { Determinasi } \\
\left(\mathbf{R}^{\mathbf{2}}\right)\end{array}$ & Persamaan Regresi \\
\hline \multirow{2}{*}{ Total Nilai Kontrak } & Hotel & 0,857 & $\mathrm{y}=-1,134+0,143 \mathrm{x}_{1}$ \\
\cline { 2 - 4 } & Kantor & 0,934 & $\mathrm{y}=0,387+0,124 \mathrm{x}_{1}$ \\
\cline { 2 - 4 } & Mall & 0,999 & $\mathrm{y}=-0,342+0,094 \mathrm{x}_{1}$ \\
\hline
\end{tabular}

Catatan: y dalam milyar rupiah dan $\mathrm{x}_{1}$ dalam milyar rupiah 
Pada dasarnya, untuk melakukan analisis regresi diperlukan data yang cukup banyak, yaitu minimal 30 data untuk setiap tipe proyek yang akan dianalisis, sedangkan pada penelitian ini data yang digunakan sangat terbatas, yaitu 7 data untuk tipe Hotel, 11 data untuk tipe Kantor, dan 10 data untuk tipe Mall. Selain itu, dalam analisis regresi harus disiapkan data tersendiri di luar data yang akan dilakukan analisis regresi untuk melakukan validasi data terhadap persamaan regresi yang didapatkan dari proses analisis regresi. Pengujian terhadap persamaan regresi bisa dilakukan dengan cara membandingkan nilai $\Delta \mathrm{y}$ terhadap nilai yteoritis. Nilai $\Delta y$ merupakan nilai mutlak dari pengurangan $\mathrm{y}_{\text {real }}$ dengan $\mathrm{y}_{\text {teoritis. }}$ Nilai $\mathrm{y}_{\text {teoritis }}$ merupakan nilai yang didapatkan dari hasil persamaan regresi. Dalam penelitian ini, tidak mungkin dilakukan validasi data karena data yang digunakan untuk menguji persamaan regresi tersebut sangat terbatas.

\section{KESIMPULAN}

Berdasarkan hasil penelitian dan analisis terhadap biaya preliminaries pada tipe proyek Hotel, Kantor, dan Mall maka dapat diambil kesimpulan sebagai berikut.

a. Persentase biaya total preliminaries terhadap nilai kontrak untuk setiap tipe proyek dapat dilihat pada tabel di bawah ini. Persentase tersebut juga dikelompokkan untuk nilai Real Cost (RC), Rencana Anggaran Pelaksanaan (RAP), dan Realisasi (REAL) dengan masing-masing memiliki nilai rata-rata, maksimum, dan minimum.

Tabel 7. Persentase Total Preliminaries Hotel, Kantor, dan Mall

\begin{tabular}{ccccc}
\hline Tipe Proyek & Nilai & RC & RAP & REAL \\
\hline \multirow{2}{*}{$\begin{array}{c}\text { HOTEL } \\
(7 \text { proyek })\end{array}$} & Rata-rata & $11,24 \%$ & $11,37 \%$ & $12,84 \%$ \\
\cline { 2 - 4 } & Maks. & $14,72 \%$ & $13,61 \%$ & $17,18 \%$ \\
\cline { 2 - 4 } & Min. & $7,18 \%$ & $7,31 \%$ & $9,54 \%$ \\
\hline \multirow{2}{*}{ KANTOR } & Rata-rata & $11,37 \%$ & $11,81 \%$ & $13,61 \%$ \\
\hline 11 proyek) & Maks. & $18,13 \%$ & $18,44 \%$ & $8,40 \%$ \\
\cline { 2 - 4 } & Min. & $6,61 \%$ & $8,77 \%$ & $8,94 \%$ \\
\hline \multirow{2}{*}{$\begin{array}{c}\text { MALL } \\
(10 \text { proyek) }\end{array}$} & Rata-rata & $8,32 \%$ & $8,31 \%$ & $13,04 \%$ \\
\cline { 2 - 4 } & Maks. & $11,11 \%$ & $11,38 \%$ & $7,21 \%$ \\
\hline
\end{tabular}

b. Persentase biaya REAL pada ketiga tipe proyek di atas selalu lebih besar dari anggaran awal yang telah disepakati yaitu RC dan RAP.

c. Persentase biaya preliminaries antara tipe proyek Hotel dan tipe proyek Kantor berada pada persentase 11,24\%-13,61\%, sedangkan tipe proyek Mall berada pada persentase 8,31\%8,84\%. Tipe proyek Mall memiliki persentase di bawah 10\% karena sebagian besar data tipe proyek Mall yang digunakan dalam penelitian ini adalah proyek Mall dalam skala kecil.

d. Hubungan antara RC dan RAP adalah memiliki nilai yang relatif tidak jauh berbeda dengan deviasi sekitar 0,5\%, sedangkan Realisasi cenderung lebih besar daripada RAP dengan deviasi sekitar 1,8\%-2,0\%. Hal ini dapat dijadikan sebagai suatu informasi penting terhadap PT X bahwa fenomena ini selalu terjadi pada proyek-proyek yang dilaksanakan oleh PT X.

e. Persentase untuk 5 item preliminaries utama terhadap total preliminaries dapat dilihat pada Tabel 8. Biaya preliminaries jika diurutkan dari yang paling dominan adalah biaya karyawan, biaya peralatan, biaya persiapan, biaya umum, dan biaya keuangan. 
Vol. 1, No. 1, April 2017: hlm 261-271

Tabel 8. Persentase Biaya Preliminaries Hotel, Kantor, dan Mall

\begin{tabular}{ccrrrrr}
\hline \multirow{2}{*}{ Tipe Proyek } & \multirow{2}{*}{ Jenis Biaya } & \multicolumn{5}{c}{ Biaya Preliminaries } \\
\cline { 2 - 6 } & & Karyawan & Peralatan & Persiapan & Umum & Keuangan \\
\hline \multirow{3}{*}{ HOTEL } & RC & $41,45 \%$ & $27,53 \%$ & $14,73 \%$ & $14,09 \%$ & $2,19 \%$ \\
\cline { 2 - 6 } & RAP & $41,13 \%$ & $24,66 \%$ & $16,97 \%$ & $15,03 \%$ & $2,21 \%$ \\
\cline { 2 - 6 } & REAL & $43,48 \%$ & $22,38 \%$ & $17,68 \%$ & $15,26 \%$ & $1,21 \%$ \\
\hline \multirow{3}{*}{ KANTOR } & RC & $43,27 \%$ & $24,27 \%$ & $15,09 \%$ & $13,65 \%$ & $3,72 \%$ \\
\cline { 2 - 6 } & RAP & $42,69 \%$ & $21,12 \%$ & $18,81 \%$ & $13,89 \%$ & $3,48 \%$ \\
\hline \multirow{nyyyyy}{*}{ MALL } & REAL & $46,72 \%$ & $17,89 \%$ & $19,02 \%$ & $13,38 \%$ & $2,99 \%$ \\
\hline & RC & $36,53 \%$ & $33,21 \%$ & $14,27 \%$ & $12,28 \%$ & $3,71 \%$ \\
\cline { 2 - 6 } & RAP & $35,37 \%$ & $34,73 \%$ & $14,81 \%$ & $11,99 \%$ & $3,09 \%$ \\
\hline & REAL & $36,24 \%$ & $32,64 \%$ & $17,28 \%$ & $12,35 \%$ & $1,49 \%$ \\
\hline
\end{tabular}

f. Pareto preliminaries dan biaya preliminaries dominan

Tabel 9 menunjukkan bahwa 5 item preliminaries telah berkontribusi terhadap 50\% keseluruhan item preliminaries. Artinya bahwa item-item tersebut harus direncanakan dengan baik untuk biaya RC dan RAP.

Tabel 9. Item Biaya Preliminaries Dominan Hotel, Kantor, dan Mall

\begin{tabular}{|c|c|c|}
\hline Tipe Proyek & 5 item preliminaries terbesar & \% terhadap total preliminaries \\
\hline \multirow{5}{*}{ HOTEL } & Gaji staf pusat & \multirow{5}{*}{ 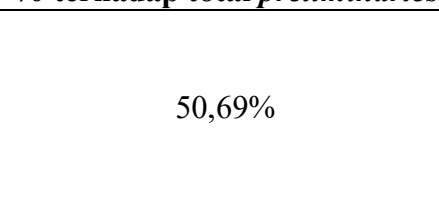 } \\
\hline & Tower crane & \\
\hline & Bahan bakar minyak & \\
\hline & Keamanan proyek & \\
\hline & Kebersihan proyek & \\
\hline \multirow{5}{*}{ KANTOR } & Gaji staf pusat & \multirow{5}{*}{$50,10 \%$} \\
\hline & Tower crane & \\
\hline & Keamanan proyek & \\
\hline & Bahan bakar minyak & \\
\hline & Kebersihan proyek & \\
\hline \multirow{5}{*}{ MALL } & Gaji karyawan pusat & \multirow{5}{*}{$50,78 \%$} \\
\hline & Tower crane & \\
\hline & Mobilisasi pekerja & \\
\hline & Bahan bakar minyak & \\
\hline & Keamanan proyek & \\
\hline
\end{tabular}

g. Dari analisis regresi dapat disimpulkan bahwa Total Nilai Kontrak Proyek sangat berpengaruh terhadap Nilai Realisasi Preliminaries dengan koefisien determinasi lebih dari 85\%, sedangkan untuk variabel lainnya tidak mempengaruhi secara signifikan.

\section{REFERENSI}

Becker, T. C., Jaselskis, E. J., and El-Gafy, M. (2014). Improving Predictability of Construction Project Outcomes through Intentional Management of Indirect Construction Costs (J. Constr. Eng. Manage., 2014, 140(6): 04014014). United States of America: ASCE

Bell, L. C. and Kaminsky, A. (1987). Data Base for Preliminary Cost Estimating (J. Transp. Eng., 1987, 113(4): 341-347). United States of America: ASCE

Diamant, L., and Roy T. (1990). Construction Cost Estimates. United States of America: John Wiley \& Sons, Inc. 
ANALISIS BIAYA PRELIMINARIES PROYEK

Rafael Devin et al.

BANGUNAN GEDUNG BERTINGKAT

(STUDI PADA PERUSAHAAN KONTRAKTOR X)

Hardie, G. M. (1986). Construction Estimating Techniques. United States of America: Prentice Hall

O’Brien, J. J. (1994). Preconstruction Estimating: Budget through bid. United States of America: McGraw-Hill

PT X. (2013). Buku Kode Biaya Pekerjaan. Jakarta: Departemen Project Control 